\title{
EVALUASI IN VITRO PADA RANSUM YANG MENGANDUNG KULIT MELINJO (Gnetum gnemon L.)
}

\author{
(In Vitro Evaluation on Ration Containing Melinjo (Gnetum gnemon L.) Cod)
}

\author{
Nina Suryanti, Eka Maya Rahmawati, Iman Hernaman, dan Ana Rohana Tarmidi \\ Fakultas Peternakan Universitas Padjadjaran, Sumedang, 45363 \\ Jl. Raya Bandung-Sumedang Km 21 Jatinangor Sumedang \\ e-mail: iman.hernaman@unpad.ac.id
}

\begin{abstract}
Melinjo cod has potential as an energy source of feed for ruminant. This study aimed to evaluate rations containing melinjo cod in vitro. The study was conducted experimentally using a completely randomized design. Data collected were analyzed for variance analysis followed by Duncan's test. The treatment was a type of ration containing $0 \%$ (R1), $10 \%$ (R2), 20\% (R3), 30\% (R4), and 40\% (R5) melinjo cod, each of which was repeated 4 times. Then the ration was evaluated in vitro. The results showed that the use of melinjo cod in the ration produced a significant difference $(P<0.05)$ on fermentability and digestibility in vitro. The use of melinjo cod did not make a difference to the concentration of $\mathrm{N}^{-\mathrm{NH}_{3}}$, but resulted in an increase $(\mathrm{P}<0.05)$ in the concentration of volatile fatty acids and high digestibility of dry matter and organic matter up to $30 \%$ with averages of $155.90 \mathrm{~mL}$, $66.79 \%$ and $67.81 \%$. It can be concluded that melinjo cod can be used in ration as much as $30 \%$.
\end{abstract}

Keywords: digestion, fermentability, in vitro, melinjo (Gnetum gnemon L.) cod, ruminant

\begin{abstract}
ABSTRAK
Kulit melinjo memiliki potensi sebagai pakan sumber energi bagi ternak ruminansia. Penelitian ini bertujuan untuk mengevaluasi ransum yang mengandung kulit melinjo secara in vitro. Penelitian dilakukan secara eksperimental dengan menggunakan rancangan acak lengkap. Data yang terkumpul dilakukan analisis ragam yang dilanjutkan dengan uji Duncan. Perlakuan merupakan jenis ransum yang mengandung $0 \%$ (R1), 10\% (R2), 20\% (R3), 30\% (R4), dan 40\% (R5) kulit melinjo dan masing-masing diulang 4 kali. Kemudian ransum tersebut dievaluasi secara in vitro. Hasil menunjukkan bahwa penggunaan kulit melinjo dalam ransum menghasilkan perbedaan yang nyata $(\mathrm{P}<0,05)$ terhadap fermentabilitas dan kecernaan in vitro. Penggunaan kulit melinjo tidak memberikan perbedaan nyata terhadap konsentrasi $\mathrm{N}_{-} \mathrm{NH}_{3^{\prime}}$ namun menghasilkan peningkatan $(\mathrm{P}<0,05)$ konsentrasi asam lemak terbang serta kecernaan bahan kering dan bahan organik yang tinggi sampai 30\% dengan rataan secara berturut-turut adalah 155,90 mL, 66,79\% dan 67,81\%. Hal ini dapat disimpulkan bahwa kulit melinjo dapat digunakan dalam ransum sebanyak 30\%.
\end{abstract}

Kata kunci: fermentabilitas, in vitro, kecernaan, kulit melinjo (Gnetum gnemon L.), ruminansia

\section{PENDAHULUAN}

Peranan pakan tidak akan terlepaskan dalam bidang peternakan karena merupakan faktor terpenting yang berpengaruh terhadap produktivitas ternak. Pakan yang kurang baik dari segi kualitas dan kuantitas dapat menyebabkan rendahnya produksi ternak. Pada kondisi tertentu, khususnya di musim kemarau sering peternak kesulitan dalam penyediaan pakan. Padahal banyak potensi pakan yang belum dimanfaatkan dan melimpah pada saat panen di lokasi produksi.
Kulit melinjo merupakan limbah dari pembuatan emping yang berasal dari buah melinjo. Kulit ini umumnya digunakan untuk campuran dari sayur asem. Pada musim panen buah melinjo, tidak semua kulit melinjo dimanfaatkan sebagai sayuran sebagian besar terbuang dan umumnya mencemari lokasi produksi. Padahal disisi lain kulit melinjo memiliki potensi yang cukup besar untuk dimanfaatkan sebagai pakan khususnya untuk ternak ruminansia. Panen buah melinjo menghasilkan kulit segar sebesar 38,27\% dari total produksi. Produksi buah melinjo secara 
nasional pada tahun 2014 mampu mencapai 197.647 ton (Direktorat Jenderal Hortikulutura Kementrian Pertanian, 2015), dari jumlah tersebut diperkirakan diperoleh kulit melinjo segar sekitar 75.640 ton.

Hasil analisis menunjukkan bahwa kulit melinjo mengandung $65,8 \%$ air, dan berdasarkan bahan keringnya mengandung $15,31 \%$ protein kasar, 1,7\% lemak kasar, 23,5\% serat kasar, $68,03 \%$ total digestible nutrient (TDN) dan $6,58 \%$ abu. Melihat kandungan nutriennya, kulit melinjo tergolong sebagai bahan pakan sumber energi (Hartadi dkk. 1991).

Informasi terkait penggunaan kulit melinjo dalam ransum ruminansia selama ini belum ada, sehingga kajian sebagai pakan ternak perlu dilakukan agar para peternak dapat memanfaatkannya, terutama di lokasi produksi.

\section{MATERI DAN METODE}

\section{Ransum percobaan}

Bahan pakan yang digunakan untuk menyusun ransum dalam penelitian yaitu kulit melinjo yang diambil dari Kabupaten Pandeglang, Banten. Rumput lapangan diperoleh dari sekitar kampus Universitas Padjadjaran, sedangkan bahan pembuat konsentrat seperti dedak padi, onggok, molases, bungkil kelapa, dan ampas kecap diperoleh dari KSU Tandangsari. Kulit melinjo sebelumnya diolah dengan cara dikeringkan di bawah sinar matahari, kemudian digiling sampai menjadi tepung, hal ini dilakukan juga pada rumput lapangan.

Ransum penelitian yang diberikan dalam bentuk ransum lengkap yang terdiri atas hijauan dan konsentrat, dengan perbandingan 30:70, dimana ransum tersebut terdiri atas berbagai level tepung kulit melinjo, yaitu: $0 \%, 10 \%$, $20 \%, 30 \%$, dan $40 \%$ dengan kandungan protein kasar $11,81 \%-12,40 \%$ dan TDN 72,27\%-73,11\%. Susunan bahan pakan untuk masing-masing ransum perlakuan dan kandungan nutriennya dapat disajikan pada Tabel 1. Kemudian ransum tersebut dievaluasi fermentabilitas dan kecernaannya dengan menggunakan metode in vitro.

Prosedur pelaksanaan uji in vitro menurut metode Tilley dan Terry (1963). Sampel percobaan ditimbang $0,5 \mathrm{~g}$ dari tiap perlakuan, kemudian dimasukkan ke dalam tabung fermentor. Menambahkan $10 \mathrm{~mL}$ cairan rumen dan $40 \mathrm{~mL}$ larutan McDaugall (saliva buatan)

Tabel 1. Susunan bahan pakan dan kandungan nutrien ransum perlakuan

\begin{tabular}{lccccc}
\hline Bahan pakan & $\mathrm{R} 1$ & $\mathrm{R} 2$ & $\mathrm{R} 3$ & $\mathrm{R} 4$ & $\mathrm{R} 5$ \\
\hline Rumput Lapangan (\%) & 30,00 & 30,00 & 30,00 & 30,00 & 30,00 \\
Konsentrat : & 70,00 & 70,00 & 70,00 & 70,00 & 70,00 \\
Dedak Padi (\%) & 11.55 & 10,79 & 8,20 & 4,37 & 0,25 \\
Onggok (\%) & 24,83 & 25,52 & 27,30 & 29,25 & 29,00 \\
Bungkil Kelapa (\%) & 16,83 & 10,14 & 5,50 & 1,00 & 0,50 \\
Ampas Kecap (\%) & 16,79 & 13,55 & 9,00 & 5,38 & 0,25 \\
Kulit Melinjo (\%) & 0,00 & 10,00 & 20,00 & 30,00 & 40,00 \\
\hline Total & 100,00 & 100,00 & 100,00 & 100,00 & 100,00 \\
\hline Kandungan Zat Makanan & & & & & \\
\hline Protein Kasar (\%) & 11,93 & 11,85 & 11,81 & 11,82 & 12,40 \\
Lemak Kasar (\%) & 5,43 & 4,97 & 4,64 & 4,29 & 4,38 \\
Serat Kasar (\%) & 15,49 & 15,10 & 14,98 & 14,90 & 15,22 \\
Bahan Ekstrak Tanpa & 59,00 & 59,10 & 60,76 & 61,42 & 60,90 \\
Nitrogen (BETN) & 8,15 & 8,98 & 7,81 & 7,57 & 7,10 \\
Abu (\%) & 72,27 & 72,30 & 72,48 & 72,55 & 73,11 \\
Total Digestible & Nutrient/TDN (\%)1) & & & \\
\hline
\end{tabular}

Keterangan : Kandungan nutrien ransum perlakuan didasarkan pada perhitungan $100 \%$ bahan kering (BK)

1)TDN $\%=2,79+1,17 \%$ PK+1,74\%LK- 0,295\%SK+0,810\%BETN (Sutardi, 2001) 
kemudian dikocok dengan menambahkan gas $\mathrm{CO}_{2}$ ke dalam tabung fermentor agar mencapai suasana anaerob dan $\mathrm{pH}$ 6,5-6,9. Tabung ditutup dengan penutup karet berpentil. Tabung dimasukkan ke dalam rak yang telah tersedia dalam waterbath dengan temperatur berkisar $39-40^{\circ} \mathrm{C}$. Tabung fermentor diinkubasi selama 3 dan 48 jam. Setelah 3 jam inkubasi, mikroba dibunuh dengan menambahkan $\mathrm{HgCl}_{2}$ jenuh sebanyak 2-3 tetes ke dalam tabung fermentor. Cairan fermentor kemudian disentrifuse dengan kecepatan 3000 rpm selama 15 menit untuk memisahkan bagian cair (supernatan) dari bagian padatan (residu), bagian yang cair digunakan untuk analisis asam lemak terbang dan $\mathrm{N}_{-} \mathrm{NH}_{3}$ dengan menggunakan metode destilasi uap Markham dan mikrodifusi cawan Conway yang dijelaskan oleh Hernaman dkk., (2015).

\section{Pelaksanaan in vitro}

Untuk inkubasi 48 jam setiap 3 jam sekali dilakukan pengocokan. Setelah inkubasi selesai ditambahkan $\mathrm{HgCl}_{2}$ sebanyak $0,25 \mathrm{~mL}$ yang bertujuan untuk mamatikan mikroba. Kemudian disentrifugasi dengan kecepatan 10.000 rpm selama 10 menit, supernatan dituang, endapan ditambah $5 \mathrm{~mL}$ larutan pepsin 0,2\% dalam suasana asam. Inkubasi kembali dalam suasana aerob selama 48 jam dengan suhu $38-39^{\circ} \mathrm{C}$ dan dilakukan pengadukan selama inkubasi. Setelah selesai, terakhir dilakukan analisis kecernaaan bahan kering dan bahan organik (Hernaman dkk., 2015).

\section{Analisis statistik}

Penelitian dilaksanakan secara eksperimental. Rancangan percobaan yang digunakan berupa rancangan acak lengkap. Data yang terkumpul dianalisis dengan analisis sidik ragam dan jika terjadi perbedaan dilanjutkan dengan uji Duncan (Steel dan Torrie, 1993).

\section{HASIL DAN PEMBAHASAN}

Evaluasi in vitro menunjukkan bahwa penggunaan kulit melinjo pada ransum mempengaruhi fermentabilitas dan kecernaan $(\mathrm{P}<0,05)$. Penggunaan kulit melinjo tidak meningkatkan nilai $\mathrm{N}-\mathrm{NH}_{3}$ Sementara itu, penggunaan kulit melinjo secara umum meningkatkan $(\mathrm{P}<0,05)$ konsentrasi asam lemak terbang, kecernaan bahan kering serta bahan organik, namun menurun nyata $(\mathrm{P}<0,05)$ setelah penggunaan $40 \%$.

Tidak berbedanya konsentrasi $\mathrm{N}-\mathrm{NH}_{3}$ yang dihasilkan dari semua perlakuan disebabkan kandungan protein kasar pada masing-masing perlakuan menunjukkan nilai yang sama. Kandungan protein kasar yang sama dalam ransum akan memberikan kesempatan yang sama bagi mikroba untuk merombak menjadi $\mathrm{N}-\mathrm{NH}_{3}$. Kadar $\mathrm{N}-\mathrm{NH}_{3}$ dalam rumen merupakan petunjuk antara proses degradasi dan proses sintesis protein oleh mikroba rumen. Jika pakan defisien akan protein atau protein tahan degradasi, maka konsentrasi $\mathrm{N}_{-} \mathrm{NH}_{3}$ akan rendah dan pertumbuhan mikroba rumen akan lambat, sehingga menyebabkan turunnya kecernaan (Hernaman dkk., 2005). Konsentrasi $\mathrm{N}-\mathrm{NH}_{3}$ dalam rumen ikut menentukan efisiensi sintesa mikroba yang pada gilirannya akan mempengaruhi hasil fermentasi bahan organik pakan. Konsentrasi $\mathrm{N}_{-} \mathrm{NH}_{3}$ dalam rumen salah satunya dipengaruhi oleh kadar protein dalam ransum (Haryanto dan Djayanegara 1993). Oleh karena itu, tinggi rendahnya protein dalam ransum akan mempengaruhi produksi $\mathrm{N}-\mathrm{NH}_{3}$.

Produksi asam lemak terbang tertinggi diperoleh pada perlakuan R4, yaitu dengan penggunaan tepung kulit melinjo sebesar $30 \%$. Hal ini mencerminkan bahwa bahan organik ransum terutama karbohidrat bentuk polisakarida mudah didegradasi oleh mikroba rumen. Namun pemberian kulit melinjo yang

Tabel 2. Fermentabilitas dan kecernaan in vitro ransum yang mengandung kulit melinjo

\begin{tabular}{lccccc}
\hline Peubah & R1 & R2 & R3 & R4 & R5 \\
\hline N-NH3 (mM) & $5,22 \pm 0,69^{\mathrm{a}}$ & $5,23 \pm 0,67^{\mathrm{a}}$ & $5,25 \pm 1,17^{\mathrm{a}}$ & $5,49 \pm 0,54^{\mathrm{a}}$ & $6,77 \pm 0,81^{\mathrm{a}}$ \\
$\begin{array}{l}\text { Asam Lemak } \\
\text { Terbang (mM) }\end{array}$ & $123,8 \pm 26,62^{\mathrm{a}}$ & $134,32 \pm 15,11^{\mathrm{ab}}$ & $143,1 \pm 39,60^{\mathrm{bc}}$ & $155,90 \pm 11,13^{\mathrm{c}}$ & $126,6 \pm 76,45^{\mathrm{ab}}$ \\
$\begin{array}{l}\text { Kecernaan Bahan } \\
\text { Kering (\%) }\end{array}$ & $62,47 \pm 0,59^{\mathrm{ab}}$ & $62,93 \pm 2,48^{\mathrm{ab}}$ & $67,50 \pm 3,98^{\mathrm{d}}$ & $66,79 \pm 3,16^{\mathrm{cd}}$ & $59,71 \pm 2,20^{\mathrm{a}}$ \\
$\begin{array}{l}\text { Kecernaaan Bahan } \\
\text { Organik (\%) }\end{array}$ & $63,77 \pm 0,91^{\mathrm{ab}}$ & $64,71 \pm 2,52^{\mathrm{ab}}$ & $68,36 \pm 4,14^{\mathrm{b}}$ & $67,81 \pm 3,67^{\mathrm{b}}$ & $60,38 \pm 3,99^{\mathrm{a}}$ \\
\hline
\end{tabular}

Keterangan : Superskrip berbeda pada baris yang sama menunjukkan berbeda nyata $(\mathrm{P}<0,05)$. 
berlebihan diindikasikan akan menyebabkan penurunan asam lemak terbang, karena setelah peningkatan asam lemak terbang pada penggunaan kulit melinjo dalam ransum sebesar $30 \%$, maka pada penggunaan sebesar $40 \%$ mulai terjadi penurunan, meskipun konsentrasinya masih sama dengan ransum kontrol (R1). Kemungkinan penurunan tersebut disebabkan karena adanya senyawa-senyawa tertentu yang dapat mengganggu proses fermentasi karabohidrat menjadi asam lemak terbang. Hasil uji fitokimia menunjukkan bahwa kulit melinjo mengandung senyawa flavonoid berupa tannin, saponin dan triterpenoid (Kusmiati, dkk., 2019). Tannin dan saponin merupakan senyawa antimikroba yang akan menghambat pertumbuhan bakteri dan protozoa $(\mathrm{Hu}, \mathrm{dkk}$. 2005; Tan et al., 2011; Wahyuni, dkk. 2014). Sementara itu, bakteri dan protozoa memiliki aktivitas dalam memfermentasi serat khususnya selulosa (Krisnan, dkk., 2009; Yanuartono, dkk. 2019) menjadi VFA. Penurunan protozoa dan bakteri diduga menyebabkan terjadinya penurunan VFA.

Asam lemak terbang yang dihasilkan selanjutnya akan digunakan sebagai sumber energi bagi induk semang, selain itu digunakan sebagai kerangka karbon untuk pertumbuhan mikroorganisme rumen, yang selanjutnya mikroorganisme ini memiliki peranannya dalam mencerna pakan dan sebagai sumber protein mikroba.

Penggunaan tepung kulit melinjo dalam ransum sampai 30\% menunjukkan nilai kecernaan bahan kering dan bahan organik yang tinggi. Kondisi ini diduga karena kandungan nutrien yang terdapat di dalam tepung kulit melinjo mudah dirombak oleh mikroba di dalam rumen, sehingga ransum yang mengandung tepung kulit melinjo termasuk bahan pakan yang mudah difermentasi. Hal ini sesuai dengan pendapat Suparwi (2000) bahwa suatu bahan pakan dikatakan fermentabel apabila kecernaan bahan keringnya minimal 60\%. Lebih lanjut ditambahkan oleh Syaro dkk. (2005) bahwa semakin tinggi fermentabilitas suatu bahan pakan, maka kemungkinan untuk dicerna oleh mikroba rumen juga meningkat yang pada akhirnya akan meningkatkan kecernaan bahan kering dan bahan organik.

Hal ini diduga bahwa ransum yang mengandung kulit melinjo memiliki kualitas karbohidrat yang lebih baik dan mudah dicerna menjadi asam lemak terbang yang juga akan dimanfaatkan untuk pertumbuhan mikroba rumen. Hal ini didukung oleh nilai asam lemak terbang yang dihasilkan, dimana penggunaan tepung kulit melinjo dalam ransum sebesar 30\% menunjukkan nilai asam lemak yang tertinggi (Tabel 2). Apabila produksi asam lemak terbang tinggi, maka akan menyebabkan aktitifitas dan pertumbuhan mikroba menjadi optimal dan pada akhirnya dapat meningkatkan kecernaan (Saripudin dkk., 2019). Sebaliknya, bila asam lemak terbang yang rendah akan menghasilkan kecernaan yang rendah pula, hal ini dapat dilihat pada perlakuan R5 penggunaan kulit melinjo $40 \%$ dengan konsentrasi asam lemak yang rendah dibandingkan dengan perlakuan R4 (penggunaan kulit melinjo 30\%) menghasilkan kecernaan bahan kering maupun bahan organik yang lebih rendah pula.

\section{KESIMPULAN}

\section{Kesimpulan}

Penggunaan kulit melinjo sampai 30\% dalam ransum menghasilkan produksi asam lemak terbang, kecernaan bahan kering dan bahan organik yang tinggi namun tidak berpengaruh terhadap konsentrasi $\mathrm{N}_{-} \mathrm{NH}_{3}$.

\section{UCAPAN TERIMAKSIH}

Penelitian ini mendapatkan dukungan fasilitas dari Laboratorium Nutrisi Ternak Ruminansia dan Kimia Makanan Ternak, Fakultas Peternakan Universitas Padjadjaran.

\section{DAFTAR PUSTAKA}

Direktorat Jenderal Hortikulutura Kementrian Pertanian. 2015. Statistik Produksi Hortikultura Tahun 2014. Direktorat Jenderal Hortikultura Kementrian Pertanian Republik Indonesia, Jakarta.

Hartadi, H., S. Reksodiprodjo dan A.D. Tillman. 1991. Tabel Komposisi Bahan. Makanan Ternak untuk Indonesia. Gadjah Mada University Press, Yogyakarta.

Haryanto, B. dan A. Djajanegara. 1993. Pemenuhan Kebutuhan Zat-Zat Pakan Ruminansia Kecil, dalam Produksi Kambing dan Domba di Indonesia, editor: Monica W., dkk. Sebelas Maret University Press, Solo.

Hernaman, I. U. H. Tanuwiria, dan M. F. Wiyatna. 2005. Pengaruh penggunaan berbagai tingkat kulit kopi dalam ransum penggemukan sapi potong terhadap fermentabilitas rumen dan kecernaan in-vitro. Bionatura, 7: 46-50. 
Hernaman, I., A. Budiman, S. Nurachma, dan K. Hidajat. 2015. Kajian in vitro subtitusi konsentrat dengan penggunaan limbah perkebunan singkong yang disuplementasi kobalt (Co) dan seng (Zn) dalam ransum domba. Buletin Peternakan, 39: 71-77.

Hu, W.L., W. Yue-Ming, L. Jian-Xin, G. Yan-Qiu and Y. Jun-An. 2005. Tea saponins affect in vitro fermentation and metanaogenesis in faunated and defaunated rumen fluid. Journal of Zhejiang University Science B, 6(8): 787-792.

Kusmiati, A., T. S. Haryani, dan Triastinurmiatiningsih. 2019. Aktivitas ekstrak etanol 96\% kulit biji melinjo (Gnetum gnemon) sebagai antibakteri Salmonella enteritidis. Ekologia: Jurnal Ilmiah Ilmu Dasar dan Lingkungan Hidup, 19(1): 27-33.

Krisnan, R., B. Haryanto, dan K. G. Wiryawan. 2009. Pengaruh kombinasi penggunaan probiotik mikroba rumen dengan suplemen katalitik dalam pakan terhadap kecernaan dan karakteristik rumen domba. JITV, 14(4): 262-269.

Saripudin A, S. Nurpauza, B. Ayuningsih, I. Hernaman dan A. R. Tarmidi. 2019. Fermentabilitas dan kecernaan ransum domba yang mengandung limbah roti secara in vitro. Jurnal Agripet, 19(2): 85-90.

Steel, R. G. D. and J. H. Torrie. 1993. Prinsip dan Prosedur Statistika. Edisi Kedua. (Diterjemahkan oleh B. Sumantri). PT Gramedia Pustaka, Jakarta.

Suparwi. 2000. Pengaruh minyak kelapa dan kembang sepatu (Hibiscus rosasinensis) terhadap kecernaan ransum dan jumlah protozoa. Animal Production, 2(2): 53-59.
Sutardi, T. 2001. Revitalisasi peternakan sapi perah melalui penggunaan ransum berbasis limbah perkebunan dan suplementasi mineral organik. Laporan akhir RUT VIII 1. Kantor Kementrian Negara Riset dan Teknologi dan LIPI, Jakarta.

Syaro, A. A., N. Jamarun, R. Saladin dan M. Zain. 2005. Pengaruh fermentasi dan defaunasi tandan kosong sawit terhadap kandungan gizi, kecernaan dan karakteristik cairan rumen in vitro. Jurnal Ilmiah Peternakan, 11: 140-141.

Tan H. Y., C. C. Sieo, N. Abdullah, J. B. Liang, X. D. Huang, and Y. W. Ho. 2011. Effects of condensed tannins from Leucaena on methane production, rumen fermentation and populations of methanogens and protozoa in vitro. J. Anim. Feed Sci. and Tech., 169: 185193.

Tilley, J. M. A. dan R. A. Terry. 1963. A two stage technique for the in vitro digestion of the forage crops. J. Brit. Grassl. Soc., 18(2): 104 106.

Wahyuningsih, N. 2010. Pengaruh penggunaan ampas Ganyong (Canna edulis Kerr.) fermentasi dalam ransum terhadap performan domba lokal jantan. Karya Ilmiah. Universitas Sebelas Maret, Solo.

Yanuartono, A. Nururrozi, S. Indarjulianto, dan H. Purnamaningsih. 2019. Peran protozoa pada pencernaan ruminansia dan dampak terhadap lingkungan. Ternak Tropika, 20(1): 16-28. 